\title{
The Myth of Faust, "Titanism", and the Religious Topic of the Selling of the Soul in the Cultural Writings of Jan Patočka
}

Petra James

Citation: James, Petra. 2021. The Myth of Faust, "Titanism", and the Religious Topic of the Selling of the Soul in the Cultural Writings of Jan Patočka. Religions 12: 528.

https://doi.org/10.3390/rel12070528

Academic Editor: Dennis Ioffe

Received: 3 June 2021

Accepted: 6 July 2021

Published: 13 July 2021

Publisher's Note: MDPI stays neutral with regard to jurisdictional claims in published maps and institutional affiliations.

Copyright: (C) 2021 by the author. Licensee MDPI, Basel, Switzerland. This article is an open access article distributed under the terms and conditions of the Creative Commons Attribution (CC BY) license (https:/ / creativecommons.org/licenses/by/ $4.0 /)$.
Department of Modern Languages and Literatures, Faculty of Letters, Translation and Communication, Université Libre de Bruxelles (ULB), 1050 Bruxelles, Belgium; petra.james@ulb.be; Tel.: +32-4-70-56-17-30

\begin{abstract}
The intensive and systematic scholarly interest in the relation of Patočka's phenomenology to religion and Christianity is recent and has only intensified over the last ten years. Thus far, the topic has mainly been studied from philosophical and theological perspectives, and the extensive body of Patočka's cultural writings has largely failed to attract the attention of scholars. Moreover, a culturological approach is virtually absent. Therefore, this article suggests focusing on the analysis of cultural archetypes in Patočka's cultural writings related to the topic of religion and Christianity from this perspective. The cultural archetypes of the Faustian figures of Patočka's cultural writings, whether Goethe's Faust, Goethe's Marguerite, or Mann's Adrian Leverkühn, are all Socratic-Christic avatars that personify Patočka's philosophical concept of "care for the soul" in the modern age. The legacy of Plato's Greek philosophy and that of Western Christianity as presented by Patočka insist on the universally shared existential experience of finitude that should be grasped as a positive challenge in the strife for meaning. Patočka's "titanism" and the archetypal titanic figures of his cultural writings are Patočkian manifestations of this universal effort. A culturological approach to Patočka's thinking on religion and Christianity might thus prove most relevant.
\end{abstract}

Keywords: Jan Patočka; titanism; Faust; Goethe; ethics; religion; Christianity; titanism; Socrates; myth; archetype

\section{Introduction}

Over the last thirty years, the philosophical writings of Jan Patočka (1907-1977), the most important representative of Czech phenomenology of the 20th century and one of the last disciples of Edmund Husserl, have been steadily acquiring their deserved place in the history of modern philosophy as well as in university programs in philosophy departments. During these decades, philosophers have been able to discover the rich and inspiring philosophical legacy of one of the leading Czech intellectuals of the 20th century, a legacy that might have been previously hidden behind the figure of Patočka as one of the key figures of the Czechoslovak dissident movement of the 1970s Charter 77. However, there are still many aspects of the rich oeuvre of Jan Patočka that deserve more in-depth scholarly investigation. As of 2011, the question of Jan Patočka's approach to religion was "virtually absent from the growing secondary literature on Patočka" (Hagedorn 2011, p. 245). Jindřich Veselý published an article in 2013 "Jan Patočka and Christianity", which is an effort to summarize the knowledge on this topic. In 2015, Eddo Evink wrote in his article that "only very recently start has been made in outlining the central status and importance of Christian ideas in his phenomenology" (Evink 2015). However, over the last decade, an important body of scholarly output was dedicated to the question, largely owing to the efforts and publication projects directed by Ludger Hagedorn. Indeed, an important milestone was the 2015 Special Issue of The New Yearbook for Phenomenology and Phenomenological Philosophy XIV. Religion, War and the Crisis of Modernity, edited by Ludger Hagedorn and James Dodd and dedicated to Jan Patočka (Hagedorn and Dodd 2015). The volume focuses on Patočka's understanding of myth and religion and is organized around 
the English translation of two of Patočka's texts on these topics, namely "Time, Myth, Faith" (1952) and the last of Patočka's studies "On Masaryk's Philosophy of Religion" (1977).

An almost exhaustive bibliography of publications dealing with the relation of Patočka's philosophical system to religion is present in the article by Martin Kočí from 2019, entitled "Christianity after Christendom: Rethinking Jan Patočka's Heresy" (Kočí 2019). Kočí focuses systematically on the relation of Patočka's phenomenological thinking to theology, most recently in an article published in French "La phénoménologie est-elle une théologie?" (Kočí 2021). The interest in the dialogue of Patočka's phenomenology and theology certainly has its precursors in the figures of Erazim Kohák (Kohák 1989, pp. 16-22) and Henri Declève, who must both be given credit for advocating and introducing, through translations, a critical bibliography, and commentaries, the works of Jan Patočka in the English-speaking and the French-speaking realm in the 1980s. Patočka's personal ties to Belgium are not limited to the figure of Henri Declève but are also related to Husserl's legacy. Indeed, on the initiative of Herman Leo Van Breda, Professor at Catholic University in Leuven, Husserl's manuscripts were transferred to Leuven just before WWII and he worked with two of Husserl's assistants, the phenomenologists Egon Fink and Ludwig Landgrebe and later also with the philosopher Walter Biemel on the edition of Husserl's manuscripts. All three philosophers were friends of Patočka, a fact that contributed to the invitation of Patočka to Leuven in the 1960s. The lectures that he held there are edited under the title Leuven lectures.

The topic of religion and Christianity is central in the well-known commentary by Jacques (Derrida [1993] 1995), in his text The Gift of Death (Donner la mort). Thus, the topic returns with renewed topicality in critical literature after a break of almost two decades to be decisively present in Patočkian critical bibliography of the last ten years. The intensive interest in Patočka's work in international academia has also boosted English translations of Patočka's major texts, though still lagging behind the French ones, where the majority of Patočka's texts are available in the excellent translations of the indefatigable Erika Abrams. We can salute the coming edition of Patočka's texts by Bloomsbury, edited by Ivan Chvatík and Erin Plunkett, which should be available in 2021 or in 2022.

We can briefly summarize several biographical facts that are developed in detail by Erazim Kohák (Kohák 1989, pp. 16-22) and by Ludger Hagedorn. Patočka was born a Catholic but in 1927 (at the age of twenty) decided to leave the Church. However, he rejoined it a year later. The interpretation of these decisions is complex. It would either be out of respect for the family tradition or, on the contrary, as a rebellion against the paternal authority, with Patočka's father, a Classics scholar, having apparently been anti-clerical. Later in life, on several occasions, Patočka allegedly considered converting to Protestantism, largely due to contacts and friendship with the theologian and Dean of the Protestant Theological Faculty at Charles University in Prague Bohumil Souček, but this intention was never acted upon (Hagedorn 2011, p. 246). The private correspondence between Patočka and Souček (so far unpublished) shows Patočka's real interest in theology and Christian practice. Patočka read Souček's sermons and his theological works, notably, New Testament critical commentaries, and discussed with him current debates on the nature of myth in Protestant liberal theology.

As Veselý affirms in his article, it is certainly interesting to note that the first of Patočka's texts "Philosophy and theology" (1929) and "On Masaryk's Philosophy of Religion" (1977) both deal with the topic of religion and Christianity (Veselý 2013). Although, as all interpreters agree, Patočka dedicated texts to Christianity throughout his life (Veselý 2013), there is an important obstacle in dealing with the topic of religion in Patočka's work. As noted by Ludger Hagedorn, " $(. .$.$) there is no text, no essay in which he deals explicitly, 'system-$ atically', with the phenomenon of religion, or attempts a comprehensive commentary" (Hagedorn 2011, p. 245). The interpreters also agree that Patočka's concept of Christianity is in many ways "heretical". As he argues, Kočí Patočka favors the phenomenological attitude towards Christianity over the metaphysical one (Kočí 2017, p. 118). However, Patočka never dismisses the question of religion and spirituality as something totally irrelevant. 
His interpretations of Christianity are multiple and are part of his argumentation in the texts dedicated to the philosophy of history and the historical and cultural meaning of Europe, but also in his cultural writings dedicated to the study of cultural archetypes. Thus far, the study of the topic of religion has been focused on Patočka's philosophical work and has been undertaken by philosophers and theologians. The present study thus aims to offer a culturological and aesthetic approach to Patočka's work with cultural archetypes related to religion and Christianity. The focus of this study will be the archetype of Faust and the concept of titanism. According to Jindřich Veselý, for Patočka, "Socrates is not a prefiguration of Christ, but Christ is an avatar of Socrates" (Veselý 2013, p. 79), and we add that we will argue in this study that Faust and Faustian avatars in Patočka's interpretations are emulations of the Socrates-Christ double model highlighted by Veselý. The evolution of these cultural archetypes throughout European history illustrates the changing form of the quintessentially European concept of "care for the soul". The Patočkian concept of "care for the soul" contains the classical and Christian legacy of European culture that Patočka strives to safeguard for the contemporary post-Christian and post-European society.

\section{Patočka's Cultural Writings}

As Patočka did not leave a systematic study of religion, we suggest turning our attention to an understudied corpus of Patočka's work, namely, a huge body of texts that we might label "cultural writings" that he had written for cultural and popular journals and that go back to the 1930s and 1940s and continue throughout Patočka's life in public debate platforms such as the magazines Kritický měsíčník, Čin, Divadlo, and Tvár̆. He is the author of influential interpretations of major figures of Czech literature, such as the key poet of Czech romanticism Karel Hynek Mácha (1810-1836), Josef Čapek (1887-1945), Jaroslav Durych (1886-1962), Ladislav Klíma (1878-1928), and Ivan Vyskočil (b. 1929). Jonathan Bolton claims in the conclusion of his recent article that "Patočka left behind a body of occasional writings that, even if he had not written a word of academic philosophy, even if he had not been a spokesman for Charter 77, would still mark him as a participant in Czech politics and culture of the twentieth century, and as a vital thinker who should not be overlooked" (Bolton 2020, p. 29).

This corpus of Patočka's cultural writings is the focus of the present article, with particular attention paid to the topic of titanism in connection to the Faust myth. The legend of Faust and its numerous variants all go back to one of the key religious and philosophical topics of Christian culture over the centuries, the "pact with the devil" and the "selling of one's immortal soul" (see James 2020; Svobodová 2021).

In his last study "On Masaryk's Philosophy of Religion" (1977) ${ }^{1}$, a substantial text on religion and its crisis in modernity, Patočka focuses not only on Masaryk but also on the topic of religion in Dostoyevsky's Brothers Karamazov, in the philosophy of Immanuel Kant and in the writings of Friedrich Nietzsche (see the discussion of this essay in Hagedorn and Dodd 2015). In this text, Patočka quotes Masaryk's affirmation that he "was experiencing metaphysics through literature". We claim that Patočka shares this shift of metaphysics towards the realm of art with Masaryk and both are in this sense representative inheritors of the Central European legacy of Romanticism. In his study of 1968, "The Social Function of Literature", Patočka gives a glimpse of his approach to the study of literary archetypes:

Literary work of art does not speak about a particular thing, but on the occasion of the demonstration of one possible relation it points out the constants of the world, which, contrary to all that is but unique, particular and arbitrary, last for ever and let shine the structure of the world as a whole. It is not about Antigone and Philoctetes, Faust and Mitya Karamazov, but about the relation of meaning, which articulates what is being, and which guides life, shapes destiny and decides about fulfillment and emptiness, about punishment and destruction. It is about the relation between nature and the supernatural, between human freedom and religious power, it is about man and God or gods, about man and 
woman about together being in work and in fighting, about guilt, suffering and death. (Patočka [1968] 2006a, p. 179)

It is significant which cultural archetypes Patočka mentions in the demonstration of his interpretative method-two figures of classical mythology and characters of Sophocles' plays, Antigone and Philoctetes, Faust and one of the Karamazov brothers. They all represent figures through which subsequent historical European epochs renegotiate their relationship to religion and metaphysics. It also shows that we can trace certain constant topics that accompany Patočka throughout his life. Antigone is one of the key archetypes for Patočka (see Bolton 2020). In his text entitled “The Truth of Myth in Tragedies of the Labdacids by Sophocles" (1971), Patočka further develops his concept of myth and its use in literary interpretations:

Against this proto-Enlightenment demand of the human being to take into his own hands his whole life and that of the polis, to let the law of the day rule everywhere, Antigone shows the supremacy of the myth, the supremacy of the whole, from which even the law of day is being nourished. The law of day, which is just a part and cancels itself, where it strives to become the whole. (Patočka [1971] 2004c, p. 466)

The emphasis on universal topics contained in literary archetypes is clearly visible. The figure of Antigone, parallel to the figure of Faust, questions human limits and thus offers a revealing mirror to the archetype of Faustian titanic figures.

\section{3. "Titanism" in Jan Patočka's Thinking}

Possibly the first mention of Faust in Patočka's writings dates to 1936 and his text “Titanism”, which is a review of Václav Černý's (1905-1987) monograph Essai sur le titanisme dans la poésie romantique occidentale entre 1815 et 1850 (Černý 1935). ${ }^{2}$ The study, published in Prague in the publishing house Orbis in 1935, was Černý's habilitation thesis, which qualified him for the position of associate professor of Romance literatures at the Charles University of Prague. The discussion of Černý's book by Patočka was a way for the young and promising philosopher to engage in a dialogue with another bright mind of Czechoslovakia. Both Černý and Patočka (30 and 28 years old in 1935), each in their own way, will go on to become two major voices of intellectual dissent in Czechoslovakia of the 1970s. The expression "titanism" used by Černý in the title of his monograph is worth commenting on. Dictionnaire historique de la langue française indicates that the French word "titanisme" is rare in French and the occurrence dates back to the beginning of the 18th century in the text of Saint-Simon. Its meaning in French is "the spirit of revolt and usurpation". Indeed, the word is not a part of common French vocabulary of the 1930s and Georges Cirot (1870-1946), a leading French specialist of Spanish literature and author of an extensive review of Černýs monograph in the prestigious Bulletin hispanique that Cirot had co-founded, mentions this fact as one of the major criticisms of the study. Indeed, he writes that one of his major regrets is that the author "did not tell us anything about the history of the word "titanism", which he employs as if it was such a common expression in French (Cirot 1936, p. 239). ${ }^{3}$ Cerný was clearly unaware of this linguistic imbalance between Czech and French. This confusion might be partly explained by the fact that the word "titanismus" figures more importantly in Czech vocabulary and is also part of the standard dictionary of Czech language. Its Czech dictionary definition implies that it is often used in a pejorative way to denounce a certain pretentious grandeur and that it refers to characteristics of a titan. However, Černý uses it in the sense that was common among Czech symbolist art and literary critics. Indeed, the word titanism is frequently used by the most important Czech critic of the end of the 19th and the beginning of 20th century, F. X. Šalda (1867-1937), who happens to be the supervisor of Černý's habilitation thesis of 1935. The use of the word titanism in Czech is rooted in a specific Central-European aesthetic and philosophical tradition, largely based on the appropriation of German romanticism and its philosophical, social and political implications. Czech symbolist art is strongly 
anchored in this cultural legacy, as is the culture of independent Czechoslovakia after 1918. The aesthetic and philosophical preoccupations of both Černý and Patočka are striking testimonies of the strength of this Central-European cultural legacy. It constitutes a shared "cultural corpus" of all the Czech intellectuals that contribute to the debate on "titanism". Indeed, "titanism" is an important part not only of Šalda's vocabulary but also of that of Tomáš Garrigue Masaryk (1855-1937). In Masaryk's use, titanism is mostly linked to his interpretation of Goethe and his Faust. Thus, to engage in a discussion on the topic of titanism in the Czech context of the 1930s is a way of positioning oneself against the most important intellectuals of Czech cultural scene of that time. Indeed, in 1935, Masaryk is still the president of Czechoslovakia and Šalda is still considered an eminent authority in Czech literary criticism. Thus, both young men, Černý and Patočka, show their ambition of affirming their place among the greatest Czech minds of their generation.

Patočka's ambition to actively participate in a public intellectual debate is visible in the choice of the magazine for his review, Čin. Indeed, Čin was not a specialized philosophical revue but one of the major platforms for cultural debate of 1920s and 1930s with contributions by important Czech artists and intellectuals. The review shows Patočka's own personal interpretation of the concept of titanism. It is important for this study because it is related to Patočka's questioning of religion. Indeed, we can study the evolution of Patočka's thinking on this topic by comparing it with the last of his texts, "On Masaryk's Philosophy of Religion", written in 1977, forty years later. Indeed, in the second text, Patočka revisits the topic and, contrary to what the title might suggest, discusses the topic of the philosophy of religion not only in Masaryk's thinking but also in that of Kant, Nietzsche, and Dostoyevsky.

As Patočka affirms, "Masaryk condenses the entire problem of Western European metaphysics in the problem of titanism" (Patočka [1936] 1989, p. 140). He goes on and quotes Masaryk's definition of titanism as a form of modern subjectivism, whose exemplar for Masaryk is Goethe's Faust. Inspired by Černý and his polemics with Masaryk from 1934 (see Černý 1934) and 1935 (Černý 1935), Patočka then goes on to critically distance himself from this view and presents his own understanding of titanism. ${ }^{4}$ We can thus claim with Veselý that the idea of titanism is key to Patočka's work on the topic of religion. Titanic figures of Patočka's cultural writings are various avatars of the cultural archetype of Faust. The concept of titanism is inspired by classical mythology and the myth of the clash of the Titans with the Gods. However, Patočka is mostly interested in the way European (and especially German) Romanticism incorporates and re-interprets the classical myth Indeed, the Romantic appropriations of the Titans Prometheus and Hyperion, inherited from classical mythology, in the works of Shelley, Keats and Hölderlin are important both for Černý in his monograph and for Patočka in his cultural writings. In his interest in the concept of titanism, Patočka (the Classics professor's son) proves to be a typical inheritor of Germanic, Central European culture of his time, centered on the study of Classics and promulgated by classical high-school and university programs. As stated above, Central European cultures have been shaped by Romanticism, with its cult of classical and national heroes and ideals represented by Goethe and Schiller. Goethe's Faust is thus a commonly shared Central European intertext of Patočka's time, a text that Masaryk remembers learning by heart at school, a text whose author was revered by Nietzsche as a precursor of the Superman. We cannot state this fact enough as it constitutes a backdrop against which Patočka develops his own interpretation of titanism, closely connected to the Faust myth. ${ }^{5}$

Patočka's interpretations are the most inspiring when they go against the most wellknown ones. Thus, contrary to Černý's and more general insistence on the element of revolt and rebellion (be it religious, metaphysical, social, or political), which is usually at the center of interpretations of Romantic titanism, Patočka insists on the element of moral, ethical responsibility that a world devoid of metaphysics casts upon man. Indeed, he writes in his review of 1936: "Titanism is a moralism, it is a moral viewpoint applied to both the world and God (... ) a moral experiment in human freedom, a test whether 
the meaning of life can be found in life itself and under what conditions ( .. ) it is the positive freedom of existence" (Patočka [1936] 1989, pp. 141, 143). Patočka thus does not share Masaryk's and Dostoyevsky's caution concerning titanism, which, for these thinkers, leads inevitably to subjectivism, nihilism, and moral decadence. Neither does he share Nietzsche's enthusiastic embrace of the vitalist forces unleashed by romantic titans. Contrary to Nietzsche, Patočka builds his concept of titanism around the key notions of personal freedom linked to a heightened responsibility for one's life in the face of the reinforced notion of one's own finitude: “Titanism no longer turns to a metaphysical power that guides the universe in resolving the question of the meaning of existence, but rather to an inner freedom that creates a personal world" (Patočka [1936] 1989, p. 141). In this sense, Patočka follows in the footsteps of Shelley (figuring importantly in Černý's monograph) when Shelley interprets the figure of the Titan Prometheus in the preface to his drama Prometheus Unbound in moral terms as "the type of the highest perfection of moral and intellectual nature, impelled by the purest and the truest motives to the best and noblest ends" (Shelley [1820] 2006, p. 776). Indeed, Patočka's understanding of titanism is not metaphysical ("a lack of an absolute faith"; a revolt against God or gods) but ethical, as a positive challenge in the strife for meaning. The review of Černýs monograph can be understood without much exaggeration as the basis for Patočka's meditations on the meaning of history and existence in his Heretical Essays of the 1970s.

Patočka's concept of titanism is thus an inheritor of Central European Romanticism, and although Patočka makes a point of distancing himself from Nietzsche, his titanism nevertheless shares with Nietzsche the fascination for the utopian ideal of the realization of human full potential. Patočka's titanism and Nietzsche's philosophy both presuppose a strong individual, capable of extraordinary (could we say superhuman?) existential courage and unflinching will. This exclusive definition of Patočka's titanism is also projected onto the various titanic figures of his interpretations, be it the idealized Socrates or his avatars evident in Patočka's take on the Faust myth. Patočka's original and counterintuitive (but also daunting) project of modern titanism points possibly to the inevitable limits related to all forms of utopian conceptualizations. Nevertheless, Patočka is unflinching in his titanic stance, and although his reading and understanding of the thinkers that he addressed in 1936 evolves, his understanding of titanism remains virtually unchanged over forty years. Thus, in his study of 1977, “On Masaryk's Philosophy of Religion”, whose first version was interestingly entitled "Humanity and nihilism", he maintains the possibility and the moral value of the titanic stance that he defends against what he sees as a reductionist understanding by Masaryk and Dostoyevsky, who equal it with subjectivism and nihilism (Patočka [1977] 2006b, p. 402).

\section{Selling One's Soul or Caring for It?}

“On Masaryk's Philosophy of Religion" proves to be an essential text for the present study. Indeed, here Patočka criticizes Masaryk for "having misunderstood the real meaning of the Faustian titanism" (Patočka [1977] 2006b, p. 402). What Patočka means by that and his own understanding of the Faustian titanism are the subject of this section. Although our main focus is on the article "The Meaning of the pact with the devil-reflections on three phases of the Faust legend" (the first, unpublished version is entitled "Reflections on three phases of the Faustian Legend Today and Yesterday: On Thomas Mann's Novel Doctor Faustus") dating back to 1972, it is important to note that Patočka's interest in the Faust theme goes back further and can be linked to the topic of titanism that Patočka comments on in a review of 1936 and goes back to his study "On Masaryk's Philosophy of Religion" (1977). He reflects on the Faust myth in his interpretation of Ivan Vyskočil's works in 1963, where his reading of Faust is preeminently political (James 2020). Patočka writes the article in 1972 with the idea of commemorating the 25th anniversary of the publication of Thomas Mann's novel Doctor Faustus (1947). The importance of this text lies in the fact that it presents Patočka's vision of the evolution of the Platonic concept of care for the soul in European civilization over the ages. This notion of philosophy of history is expressed by 
the original title of the study, "Reflections on three phases of the Faust legend Faustian Legend Today and Yesterday". The way the archetype of Faust evolves through the ages reveals what "selling one's soul" means in any given historical moment and, thus, in a mirror image, what caring for one's soul looks like.

After the events of the Soviet and Warsaw Pact armies' invasion of Czechoslovakia in 1968, Patočka had to retire from his university position in 1972 and his publication opportunities in Czechoslovakia became limited. The Faust text was finally published in two revised and slightly different versions in Polish and in German. The text was clearly important for Patočka. Nevertheless, it took considerable time, effort, and intervention of Patočka's colleagues abroad before it could be published. The text was ready in 1972, and in a letter to his friend Walter Biemel (German phenomenologist of East-CentralEuropean descent and editor of Husserl's and Heidegger's texts) from 20 September 1972, Patočka writes that, thus far, all the German journals that he had contacted rejected the article. According to Patočka, Thomas Mann did not seem like a topical theme either for philosophy or for literature or human sciences (Vojtěch and Chvatík 2004, p. 408). Patočka sums up the central theme of his article as the "reflection on the character of myth, on poetry as a means of working through basic mythical themes (such as the myth of the soul)" (Vojtěch and Chvatík 2004, p. 408). Biemel contacts Jean Améry and asks for his help. Améry likes the text and writes a recommendation. However, in the end, it is the phenomenologist Ludwig Landgrebe, another of Husserl's disciples and friend of Patočka's, who succeeds in securing the publication of the article in 1973 in the well-respected journal Neue Zeitschrift for Systematische Theologie und Religionsphilosophie, still published today by the renowned publishing house De Gruyter, and dedicated to "the exciting dialogue between Lutheran-Reformed theology and philosophy in the broadest sense". It was Landgrebe who suggested the title of the article, "The Meaning of the pact with the devil", so that the "religious-philosophical content" (Vojtěch and Chvatík 2004, p. 409) would be clearly evident. The Polish version was published owing to the efforts of Patočka's Polish translator (for details, see Vojtěch and Chvatík 2004, p. 409).

The text is significant for several reasons. Patočka writes in a private letter that this article is his attempt at a "philosophy of literature". The text is also an example of the centrality of philosophy of history in Patočka's thinking. The legendary topic of Faust and its variations by Goethe and Mann are Patočka's attempts at formulating the philosophy of German national destiny, with Faust being seen by Patočka as a typical German theme. Moreover, as he points out at the end of his essay, the gradual shifts in the representation of Faust illuminate at the same time European history and all of humanity at the threshold of what he calls the "post-European epoch" (Patočka [1972] 2004e, p. 119). Therefore, it is possible to read this text in parallel with the best-known text by Patočka, his Heretical Essays in the Philosophy of History (published in samizdat, in Ludvík Vaculík's Edice Petlice in 1975).

In the fifth of his Heretical Essays, Patočka also mentions Faust in his description of the evolution of the philosophical concept of responsibility (Patočka [1990] 1996, p. 105). Indeed, in Patočka's thinking, the interpretations of art and literature are inseparable from the evocation of religious, ethical, and civic categories. Among them, the concept of responsibility plays a central role. Thus, we can see this text as another effort by Patočka to illuminate his concept of "care for the soul". Indeed, the highly metaphorical theme of Faust is interpreted by Patočka as the motif of "selling one's immortal soul" (Patoč ka [1973] 2004f, p. 511). ${ }^{6}$ However, the selling of one's soul is just the reverse side of the Platonic/Patočkian "care for the soul", a concept whose core theme is again individual "responsibility". The centrality of the concept of responsibility in Patočka's thinking is also highlighted by Jacques Derrida in his Gift of Death (Donner la mort), based on the interpretation of the mentioned fifth Heretical Essay (Derrida [1993] 1995, p. 91). Thus, how does one care for his or her soul in Patočka's philosophical world? Patočka is Socratic and Platonic in the sense that his philosophy is a permanent effort to rise to the challenge to the fundamental Socratic question of "how should we live?" The Greek philosophical concept 
of "care for the soul" in its Socratic-Platonic variant is ever present in Patočka's writings in the 1970s, Post-European Epoch and its Spiritual Problems (1970), in the interpretations of Plato in the text The beginnings of systematic psychology (1971), About soul by Plato (1972), Plato and Europe (1973), and Europe and Post-European Epoch (1970-1977) (Josl 2018, pp. 23-24). In all of these texts, Patočka revisits the concept of "care for the soul" and explains in detail his understanding of it. The motif of immortality is understood and interpreted in ethical and philosophical terms. Indeed, the definition that Patočka gives of immortality is that of ethical integrity and responsibility: "The immortality in its right sense is achieved by those who prefer non-being to the destruction of one's soul" (Patočka [1972] 2004e, p. 511). ${ }^{7}$ The figure of Socrates is clearly on Patočka's mind when he talks about true immortality as the courage to choose death as the price for preserving one's philosophical coherence and ethical integrity: "True immortality is for those, who overcame the horror of physical death by the horror of an absolutely negative existence, so that they could achieve what is achievable at the height of this life: one's finite absoluteness" (Patoč ka [1973] 2004f, p. 512). ${ }^{8}$ Socrates is described in the text on Faust as a figure of "ethical being in the world". Socrates's choice is summed up by Patočka as the choice between "possible annihilation as a way of preserving one's authenticity" and "prolonging of one's life as a denial of one's true self" (Patoč ka [1973] 2004f, p. 511). The texts on Faust thus reflect Patočka's parallel work on the concept of soul by Plato and reflect the meditations on the sense of history. As Martin Kočí claims, "Patočka's whole project of caring for the soul is about caring for death, and thus searching for the meaning of life in spite of finitude" (Kočí 2019, p. 12).

In Patočka's texts on Plato, concern for ethics and for the concept of freedom are central, as in the interpretation of soul in About Soul by Plato (1972). As Jan Josl remarks, according to Patočka, Plato starts from "the human existence in this original crisis and problematic aspects, which is fundamentally ethical, that is such, that it is concerned with our own existence and non-existence, partially dependent on us, on our decision" (quoted according to Josl 2018, p. 25). ${ }^{9}$ In his aforementioned interpretation of Heretical Essays, Jacques Derrida insists on Patočka's concept of responsibility inspired by Plato while quoting in the support of his argument the following passage from Heretical Essays: "Plato's doctrine of the immortality of the soul is the result of the confrontation of the orgiastic with responsibility" (Derrida [1993] 1995, p. 270).

\section{Marguerite-A Socratic Faust?}

It might come as a surprise that in a text on Goethe's Faust we learn more about Socrates than about Goethe or Faust. Patočka's cultural writings tend to be the most interesting, where they deliberately, although often tacitly, depart from previous, more well-known interpretations and challenge them with an original twist. Considering the fact that Goethe's Faust is one of the most frequently interpreted texts in the German language and of the key texts of European literature, Patočka cannot be accused of lacking in ambition. In the following central passage, Patočka gives his personal interpretation of Goethe's Faust: "and from here it is important to understand, how the mishearing of that proper inner motif arrives - that it is guilt that drives this movement-and why Faust is more and more understood as a man of energy, as a superman in the modern post-idealistic sense" (Patoč ka [1973] 2004f, p. 517). Patočka puts in the center of his interpretation moral categories and emphasis on the key role of Goethe's Faust existential experience of guilt ("it is guilt that drives this movement") as the true driving force behind his actions, not his pride or the thirst for knowledge. He goes on to claim that the previous interpretations are but a "mishearing of that proper inner motif", which basically amounts to claiming that the other interpretations did not understand the meaning of Faust correctly. And who might these authors, never directly mentioned in Patočka's text, be? The thinkers thus challenged are no minor intellectual figures: Hegel, Nietzsche, and Masaryk.

Hegel's reading of Goethe's Faust is probably the most well-known and the most influential. Hegel's philosophy and his thinking on aesthetics often function as Patočka's intertext, a philosophical work with which he is constantly in dialogue. Indeed, Patočka 
was intimately acquainted with Hegel's oeuvre, not only as a philosopher but also as a translator of two of his major works, The Phenomenology of Spirit, translated by Patočka in Czech and published in 1960, and his Aesthetics, published in Czech in 1966 with a large introduction by Patočka entitled Hegel's Philosophical and Aesthetic Evolution, which we Patočka's own interpretation of Hegel. Patočka, who literally knew both Hegel and Goethe by heart, refers to Hegel's interpretation of Goethe in the Phenomenology of Spirit in his study "The German Spirit in Beethoven's Era" (Německá duchovnost Beethovenovy doby) of 1971 (Patočka [1971] 2004d, p. 471). Patočka mentions Hegel twice (and only briefly) in the published version of his Faust text. Patočka was probably aware that the quote from Goethe's Faust in Hegel's Phenomenology, published in 1807, is that of the first version of Faust, Part One, the revised version being published in 1828-1829, and Faust, Part Two was published posthumously in 1831. It is also quite possible that Patočka was aware of a highly personal appropriation by Hegel of Goethe's text, in that he sometimes misquotes and uses it as a practical way of demonstrating his philosophical concept (see Champlin 2011). It is maybe this aspect of Hegel's use of Goethe's Faust that inspires Patočka to use the same text for the demonstration of his own philosophy. Indeed, an indirect polemics with Hegel might be seen in the central position that Patočka assigns to the character of Marguerite. Whereas in Hegel's reading all the victims of Faust's doings are dismissed as metaphorical "collateral damage" of Faust's gradual spiritual elevation, Patočka interprets Marguerite as the key character and the only real tragic figure of Goethe's Faust. Indeed, Marguerite and her destiny come to the forefront, and she is interpreted as a Platonic character: "what makes Faust in Goethe's conception into a real tragedy, what carries it, is the tragedy of Marguerite: the punishment is in a quintessentially platonic way experienced as the purification of soul and external help is refused as appearing opposed to being" (Patoč ka [1973] 2004f, p. 516). Patočka thus offers us a surprising and original interpretative angle with the reversal of roles. Marguerite is the female version of Hegel's Faust as a symbol of spiritual growth and elevation of the spirit. At the same, she is yet another avatar of Patočkian titanism of moral responsibility. Her choice is again interpreted by Patočka in Socratic terms as an ultimate ethical choice and a radical way of "care for the soul". The oblique dialogue with Hegel is a recurrent phenomenon in Patočka's literary interpretations. Indeed, Jonathan Bolton points out that one of the key aspects of Patočka's interpretation of Sophocles' tragedy Antigone is actually his refusal of Hegel's famous political reading of the play (Bolton 2020). The "spectral" presence of Hegel in Patočka's cultural writings would certainly deserve a more in-depth study.

Another crying absence in Patočka's Faust text is that of Masaryk. Masaryk as an intellectual and a symbolic figure is someone that every Czech thinker of the first half of the 20th century needed to come to terms with. Patočka's life-long engagement with Masaryk's thinking is thus coherent with Masaryk's status as one of the leading Czech intellectuals of his time. The title of Masaryk's most well-known take on Goethe and his Faust is self-explanatory: "Goethe's Faust: Superman", originally published in 1896 and later integrated into one of his major works, Modern Man and Religion (Masaryk [1896] 1938). As we already remarked in the section on titanism, Patočka is quite critical of Masaryk's reading of Goethe (whom Masaryk famously called "the Giant of Dilettantism") and the assimilation of Goethe's titanism with a negative notion of subjectivism, which for Masaryk leads to nihilism. Patočka proves to be a more sophisticated theoretician of literature than Masaryk when Patočka castigates Masaryk for confusing Goethe with his literary character of Faust. Patočka also refuses Masaryk's Nietzschean reading of Faust: "Faust is the real titan, he is the superman" (Masaryk [1896] 1990, p. 75). Nevertheless, and maybe surprisingly, we might find some parallels in Masaryk's and Patočka's interpretations of Faust. Indeed, Masaryk goes on to say about Faust that "He is a titan of reason but a coward of heart" (Masaryk [1896] 1990, p. 75). Indeed, Patočka does not shy away from reprimanding literary characters for their lack of moral courage and integrity. Thus, in a sketch comparing the characters of Ludvík Vaculík's novel Axe and Milan Kundera's novel The Joke, Patočka pitches the moral purity of the character of the father in Vaculík's novel 
(which Patočka calls "the law of the heart", Gesetz des Herzens) against Kundera's novel's "overall weak figures", whose main hero is incapable of catharsis (Patočka [1968] 2004b, p. 212). The classical aesthetic category of catharsis remains relevant for Patočka's work with cultural archetypes. Catharsis is central to the way Patočka describes both Goethe's characters, Faust, and Marguerite. According to Patočka, "Marguerite's grand will for self-sacrifice, which spiritualizes her and leads her to refuse earthly 'salvation', makes the Faust of Goethe's version (despite his seemingly cynical banality) believe in a higher meaning of life and take the path of purification" (Patoč ka [1973] 2004f, p. 525). ${ }^{10}$ The English word "spiritualize" is the translation of the Czech verb "oduševňovat", which literally means "to infuse someone with soul". It is thus by acquiring soul, the strength of the heart, that Marguerite also acquires the moral and spiritual capacity to elevate Faust through her sacrifice. Masaryk's remark on the weakness of Faust's heart acquires a new resonance with Patočka's own interpretation of Goethe's Faust-it is also constructed around classical ethical categories inherited from Socrates and Plato, which put forward the value of personal responsibility. Indeed, this role given to Marguerite brings further distance from Hegel's interpretation. Instead of the elevation of the spirit coming from the outside through education, art, and philosophical training, it is driven by personal change; it comes first from the inside, from the "heart", from the "soul". This critical debate with Hegel and his concept of art continues in the article in Patočka's interpretation of the figure of Adrian Leverkühn.

\section{Mann's Adrian Leverkühn: An Übermensch of Responsibility?}

The second and larger part of Patočka's interpretation of the Faust myth is dedicated to Mann's novel. Patočka focuses on the question of how to stage the Faust motif of the pact with the devil and of the selling of one's immortal soul in an era and in a society where the very notion of a soul had lost all its relevance, the historical moment of Thomas Mann, that of post-WWII Germany. It is interesting to note that in this text, Patočka mentions Nietzsche only once and very briefly. This is of course highly significant, as Patočka must have been aware of the fact that Mann constructed the figure of Adrian Leverkühn around important biographical and philosophical details of Nietzsche and his work. Indeed, as Andrew Erwin remarks, “Since its inception in 1947, Thomas Mann's Doktor Faustus has been referred to as a Nietzsche-novel, and the parallels between Nietzsche and the novel's protagonist Adrian Leverkühn have been well documented" (Erwin 2010, p. 283). It is thus worth the effort to think about the reasons for this deliberate omission of the philosopher. In an article from 1966 dedicated to the history of Epos and Greek drama, Patočka also refers to Nietzsche indirectly, not mentioning his name but referring to him obliquely as a "spirited and dangerous thinker" (duchaplný a nebezpečný myslitel, Patočka [1966] 2004a, p. 348). We might even advance a provocative theory according to which Patočka sketches out a portrait of Nietzsche as he would have liked him, a responsible and ethical Nietzsche, an Übermensch, a titan of responsibility. By not directly mentioning the Nietzsche analogy of Leverkühn's character, Patočka projects into the figure his ideal version of Nietzsche, a Nietzsche who would have adhered to Patočka's concept of titanism. The fall of the main character of Mann's Doctor Faustus is therefore logically interpreted by Patočka as the taking on of universal responsibility, which means the loss of the titanic soul (and thus madness and subsequent death). However, by "losing his life", Adrian Leverkühn in Patočka's interpretation paradoxically acquires an immortal soul.

The destinies of individuals, art, and European civilization are put in a chain of cause and effect. In Patočka's view, where he continues in his tacit discussion with Hegel, Mann follows German romanticism in its faith in the central role of art as a form of the spiritual renewal of human beings and the tool of their education. As art unifies the spiritual and the sensual, it enables man to become whole again. Art is the "symbol and gate leading towards practical freedom" (symbol a brána k praktické svobodě, Patočka [1972] 2004e, p. 117). This was, according to Patočka, the project of spiritualization (zduchovněni, Patočka [1972] 2004e, p. 117), with which "the great men of their time stepped out against the total secularization 
of the modern era and against a partial Enlightenment" (Patočka [1972] 2004e, p. 117) ${ }^{11}$. After this personal paraphrase of Hegel and the focus of German Romantic philosophy, Patočka goes on to explain how the Hegelian project of German Romanticism of care for the soul gets modified in post-WWII Germany and how it is represented by the figure of Leverkühn. As Patočka affirms, Adrian (in accordance with his romantic forefathers) also insists on the intrinsic link between the renewal of art and of man. However, the relation is reversed. It is not art that causes spiritual renewal of man, but an ethically responsible, "soulful" man (the man who reacquired a soul, as Marguerite did) that will renew art of his era:

[ ... ] first, it is important to acquire the dimension of responsibility, therein should emerge 'the immortal soul', and then, as a result of this healing, a breakthrough towards a new art, which would thus be a suitable bearer of further renewal. The spiritual and artistic renewal is thus not divided into stages but is seen together. (Patočka [1972] 2004e, pp. 117-18) 12 $^{12}$

This peculiar quote creates a link between the acquisition of responsibility and the emergence (the possibility) of the "immortal soul". Only through this transformative experience can modern art also be transformed. It is thus the individual human being that is the starting point of the epochal spiritual renewal; a renewal does not happen in stages, as in Hegel's philosophy, but can occur all at once, through a transformative experience of personal metanoia. Indeed, Leverkühn is in Patočka's vision the titan of the new spirituality for contemporary Europe/the world, and, at the same time, he is the figure of a radical, "pure" sacrifice, which has for its aim the renewal of men and art. Indeed, Leverkühn is the post-WWII avatar of the Socratic-Christic archetype and a representation of a new type of "care for the soul" in an era that is both post-Christian and post-European. He is the modern titan of the Night, who, by his choice, refuses the survival of the bare life as the supreme value of existence (a theme that Patočka further develops in the sixth Heretical Essay) and chooses, as Socrates did, the sacrifice of life in the name of preserving a certain kind of transcendence and soulfulness. He thus, according to Patočka, needs to take on "not only the role of Faust but also that of Marguerite" (Patočka [1972] 2004e, p. 114), and their mutual salvation is combined in the final "salvation" of Leverkühn (Patočka [1972] 2004e, p. 118). The concept of responsibility comes again as a leitmotif of Patočka's work with cultural archetypes and is placed as a conclusion of the interpretation of the figure of Mann's Leverkühn: "This universal accountability and the will for it-the universal responsibility-is also the last legacy of Leverkühn as a man and that of his music, the music of that difficult era, which, as he knows, opens up during his lifetime" (Patoč ka [1973] 2004f, p. 523).

\section{Jan Patočka and the Archetype of the Hero}

Patočkian titanism is key to the understanding of Patočka's Socratic figures and their avatars (which also inspire his concept of political and civic dissent; see for example, Patočka's samizdat article of 1976 "The Heroes of our Time"). It is confirmed and revisited in many texts of the 1970s, for example, in his important lecture of 1975 "The Spiritual Person and the Intellectual" (Duchovní člověk a intelektuál), prepared at the same time as the Heretical Essays. In "The Spiritual Person and the Intellectual", Patočka makes a point of distinguishing between a pragmatic intellectual and a real "spiritual person" (duchovni člověk). Contrary to the pragmatic intellectual (we could say, the sophist of Socratic dialogues), he pitches the spiritual person, the person who can care for her/his soul. As a demonstration of proper "care for the soul", he surprisingly chooses the Homeric archetype of courage, the famous hero of the Iliad, Achilles: "The very figure of Achilles, the man who chooses that short life of glory! Something that goes against the direction of the ordinary life, something that belongs to the foundations of Greek political feeling" (Patočka [1975] 2002, p. 360). ${ }^{13}$ The way he describes Achilles makes us think more of the Socratic type of courage and therefore is again a demonstration of the project of "care for the soul". Indeed, Patočka, well read in Socratic dialogues and well acquainted with Plato's reflections on 
courage and manliness (andreia), emulates Plato's renegotiation of the Homeric archetype of courage, adding to the traditional archetype of Achilles that of a philosophical courage, represented by the Socratic archetype (Hobbs [2000] 2006). Indeed, the courage of a philosopher (Patočka's spiritual person) is the central Platonic archetype of courage, the one capable of facing all adversities of destiny with calm and composure, even in the proximity of death, as Socrates did. Patočka's Achilles is less the famous Homeric fierce fighter and merciless adversary driven primarily by the desire for eternal glory gained on the battlefield and more a self-reflecting Socratic philosopher of Plato's dialogues dedicated to courage of the spiritual person that appears in the final passages of Patočka's sixth Heretical Essay, someone whose life's meaning has been shaken by the front experience (here, the analogy with Achilles is very appropriate). In the experience of the existential "shaking" (otřesení), Patočka's Achilles/Socrates/Faust/Marguerite/Adrian/Spiritual person chooses the maximal existence of life "at the peak", "the short and glorious life", in order to honor one's own inner integrity and achieve Patočkian immortality. The spiritual person experiences a real existential metanoia, which makes her/ him choose counter-intuitively against the rules of the ordinary life of the polis, against the rules and laws of the day, as Patočka so pointedly stresses in his interpretation of Sophocles' Antigone, the mirror image of Faust. The titanic aspect of this singular choice is evident here, as well as the parallels with the reflections on immortality developed by Patočka in his Faustian meditations. It is the titanism of heightened moral awareness and towering responsibility as Patočka redefined it in his text of 1936. The cultural archetypes of Faustian figures of Patočka's cultural writings, be it Goethe's Faust, Goethe's Marguerite or Mann's Adrian Leverkühn, are all Socratic-Christic avatars that personify Patočka's philosophical concept of "care for the soul" in the modern age.

\section{Conclusions}

Patočka's highly personal and unusual analyses of Faust, one of the key cultural archetypes of Central-European culture, also point at what Patočka considers to be the cultural and spiritual legacy of (Central) European civilization that "comes after (the end of) Christendom" (Kočí 2019, p. 9). These ideas are further developed in Heretical Essays (1975) and in the study "On Masaryk's Philosophy of Religion" (1977). In this sense, Patočka is a quintessentially Central European philosopher. This "peripheral" perspective might be one of the reasons for the renewed interest in Patočka's work over the last two decades, which, paradoxically, and despite (or because) European integration, poses real questions about European identity and its place in the globalized world. Patočka offers Europeans the opportunity to think about their common and shared identity and their core historical values while focusing on cultural legacy rather than on politics or economics. In Patočka's Central-European perspective, "Europe ( . . ) is the ideal of rational life directed toward truth based on insight. Europe is the culture of insight, that is, a scrupulous reflection on that which appears. Further, insight is the condition of the possibility of the 'spiritual life', 'life in truth', or alternatively, 'care for the soul'" (Kočí 2019, p. 2). According to Patočka, it is care for the soul (tes psychés epimeleia) that gave rise to Europe (Heretical Essays 1975) and the self-reflecting soul is the core legacy of European culture, that is, the critical notion of the problematicity of one's own existence. In his final study, "On Masaryk's Philosophy of Religion", Patočka continues the dialogue with Nietzsche and Masaryk, this time openly and explicitly. It is also in this text that he returns to his initial reflections on the nature of titanism. Patočkian "care for the soul" is an original Central-European synthesis of the core cultural and spiritual legacy of classical Greece and Christianity. Patočkian "care for the soul" is built on the existential experience of finitude as the universally shared experience of being (Kočí 2019, p. 12). According to Patočka, this experience must be accepted both by individuals and the community as a positive challenge in their strife for meaning. Patočkian titanism and archetypal titanic figures of his cultural writings are representations of this universal effort and manifestations of Patočkian "care for the soul". 
Funding: This research received no external funding.

Institutional Review Board Statement: Not applicable.

Informed Consent Statement: Not applicable.

Data Availability Statement: Not applicable.

Acknowledgments: I would like to thank the director of Jan Patočka Archive in Prague, Jan Frei, for giving me the access to the private correspondence of the theologian Bohumil Souček and Jan Patočka.

Conflicts of Interest: The author declares no conflict of interest.

\section{Notes}

1 Tomáš Garrigue Masaryk (1850-1937) was one of the leading Czech intellectuals of the second half of the 19th and the first half of the 20th century. Philosopher, sociologist, and politician, he is credited with the foundation of Czechoslovakia. He was the country's president from its foundation in 1918 until 1935.

2 Václav Černý was one of the leading Czech intellectuals of the 20th century. Professor of Romance studies, his main scholarly interest was in the Baroque period and in Romanticism in Czech, Spanish and French literatures. Patočka does not mention in his review that in 1934 Černý published an article entitled “Quelques remarques sur la critique masarykienne du titanisme romantique" in Revue de littérature comparée (published by the renowned academic publisher Honoré Champion, vol. 14, 1 January 1934). The text becomes a chapter of the 1935 monograph. The article reacts to the publishing of Masaryk's book Modern Man and Religion in 1934 (Moderní člověk a náboženství, Prague, J. Laichter). Although the content of Masaryk's book had already been published in magazines in 1890s, the publication in a book form renewed the debate on the topic.

3 “( . . ) M. V. C. ne nous ait rien dit sur l'histoire du mot titanisme, qu'il emploie comme s'il était tellement courant chez nous".

4 Patočka's tacit dialogue with Černý's concept of tianism and its significance in Czech culture will be further explored in a separate study. For more detailed study of Černý's work, see the monograph of Júlis Vanovič (1999), Osobnost' Václava Černého.

5 Apart from the already mentioned culturological approach to the study of literature that Patočka adopts, there is another factor that shapes his study of the myth of Faust, and that is the intellectual discussion of the nature of myth, especially the one developed within the realm of German Protestant liberal theology of the 1940s and 1950s by theologians such as Karl Barth or Rudolf Bultman. An important testimony of the theoretical impulse of theology for Patočka's thinking on myth is represented by the private correspondence between Patočka and the Protestant theologian Bohumil Souček. A relationship that started as an intellectual confrontation developed into a lifelong friendship (see Veselý 2013). The debate on myth between the two thinkers was particularly lively in the 1940s and the first half of the 1950s. This unpublished correspondence is an under-researched source and should be explored in more depth by theologians.

6 "[... ] problém prodeje nesmrtelné duše".

7 “Nesmrtelnost duše v pravém smyslu dosáhnou ti, kdo dají přednost nebytí před zkázou duše".

8 “Pravá nesmrtelnost je zde pro ty, kdo hrůzu z tělesné smrti překonali hrůzou z absolutně negativní existence, aby dosáhli toho, čeho je možno dosáhnout na vrcholku vezdejšího života: své konečné absolutnosti".

9 “[ . . . ] z lidského bytí v jeho základní krisis a problematičnosti, která je bytostně mravní, tj. taková, že v ní běží o naše vlastní bytí a nebytí v částečné závislosti na nás, na našem rozhodnutí [ . . ]".

10 “Velkolepá vůle k sebeobětování, která oduševňuje Markétku a vede ji k pohrdnutí pozemskou 'záchranou', přivádí Fausta Goethovy verze k tomu, že přes zdání své cynické banálnosti uvěří ve vyšší smysl světa a vydá se na cestu očisty".

11 “[ ... ] s níž velikáni tehdejší doby vystoupili proti úplnému zesvětštění moderní doby a jednostrannostem osvícenství." (Patočka [1972] 2004e, p. 117).

12 “Obnova umění a člověka patří k sobě, na tom trvá i Adrian, ale jejich vztah vidí spíše naopak: napřed je třeba získat dimenzi zodpovědnosti, v ní se má vynořit 'nesmrtelná duše', a potom, jako výsledek tohoto uzdravení, průlom k novému umění, které by tak bylo vhodným nositelem další obnovy. Duševní a umělecká obnova tak vlastně není rozložena do etap, nýbrž naopak viděna pohromadě". (Patočka [1972] 2004e, pp. 117-18).

13 “Samotná postava Achillea—člověk, který si vybere ten krátký a slavný život! Něco takového, co jde proti směru běžného života, něco takového, co patří k základu řeckého politického citu".

\section{References}

Bolton, Jonathan. 2020. A Guest from the Unknown: Antigone and Jan Patočka's Cultural Criticism. Bohemica Litteraria 23: 13-30. [CrossRef]

Černý, Václav. 1934. Quelques remarques sur la critique masarykienne du titanisme romantique. Revue de Littérature Comparée 12: 661-76. Available online: https:/ / www.proquest.com/scholarly-journals / quelques-remqrques-sur-la-critique-masarykienne/ docview /1293244331/se-2?accountid=201395 (accessed on 2 July 2021). 
Černý, Václav. 1935. Essai sur le Titanisme dans la poésie romantique occidentale entre 1815 et 1850. Prague: Orbis.

Champlin, Jeffrey. 2011. Hegel's Faust. Goethe Yearbook 18: 115-25. [CrossRef]

Cirot, Georges. 1936. Compte rendu de Václav Černý. Essai sur le Titanisme dans la poésie romantique occidentale entre 1815 et 1850. Bulletin Hispanique 38: 235-41. Available online: https://www.persee.fr/doc/hispa_0007-4640_1936_num_38_2_2725_t1_0235_0000_3 (accessed on 2 July 2021).

Derrida, Jacques. 1995. The Gift of Death. Chicago: The University of Chicago Press. First published 1993.

Erwin, Andrew. 2010. Rethinking Nietzsche in Mann's Doktor Faustus: Crisis, Parody, Primitivism, and the Possibilities of Dyonisian Art in a Post-Nietzschean Era. The Germanic Review: Literature, Culture, Theory 78: 283-301. [CrossRef]

Evink, Eddo. 2015. The Gift of Life. Jan Patočka and the Christian Heritage. London and New York: Routeledge, Available online: https:/ /bookshelf.vitalsource.com/\#/books/9781317410010/cfi/6/32!/4/2/4@0:0 (accessed on 2 July 2021).

Hagedorn, Ludger. 2011. Beyond Myth and Enlightenment: On Religion in Patočka's Thouhgt. In Jan Patočka and the Heritage of Phenomenology. Centenary Papers. Edited by Ivan Chvatík and Erika Abrams. London and New York: Springer, pp. $245-61$.

Hagedorn, Ludger, and James Dodd. 2015. The New Yearbook for Phenomenology and Phenomenological Philosophy XIV. Religion, War and the Crisis of Modernity. Edited by Ludger Hagedorn and James Dodd. London and New York: Routeledge.

Hobbs, Angela. 2006. Plato and the Hero: Courage, Manliness and the Impersonal Good. Cambridge: Cambridge University Press. First published 2000.

James, Petra. 2020. On Mastodons, Faust and Tight Hugs: Jan Patočka on Literature. Bohemica Litteraria 23: 51-68. Available online: https://www.phil.muni.cz/journals/index.php/bohemica-litteraria (accessed on 2 July 2021). [CrossRef]

Josl, Jan. 2018. Uměni a péče o duši. Prague: Karolinum.

Kočí, Martin. 2017. The Sacrifice for Nothing: The Movement of Kenosis in Jan Patočka's Thought. Modern Theology 33: 594-617. [CrossRef]

Kočí, Martin. 2019. Christianity after Christendom. The Heythrop Journal, 1-14. Available online: https:/ /d1wqtxts1xzle7.cloudfront. net/59548340/2019_Christianity_after_Christendom.pdf?1559824702=\&response-content-disposition=inline \%3B+filename\% 3DChristianity_after_Christendom_Rethinkin.pdf\&Expires=1626079883\&Signature=RPkELaAPjLO2fqc0bNorW7ZbdQ3E \{\}NBqNjZBBKPEKZTfQ \{\}-SkgEjec1Puj-8jOhMNgJ977vDujlnSMwBvJd0mdVZenJ8Wp9PCDiUfy \{\}fptMt76GgVRpW9GpJ8 3JqXOrsZuCgQFByE-i03ZP86T13ML \{\}y2FQiQ6jLCSAcQmiww3TjEylzdEot8uE-YOb4fh-jWk9bKpRzQU5ZAstJKwpayT4 WLRo65PWnlFhWSNKMUBATsJgr196A37qpOBUzEgN7hCfWy1Bbyp5EJPivpq \{\}XEOPz367swxVDOL0fGY4x17NW \{\}yhFG4ydhF-VcyOFfGtpDVTyQZNWGXLUocF7kKVEg_\&Key-Pair-Id=APKAJLOHF5GGSLRBV4ZA (accessed on 2 July 2021).

Kočí, Martin. 2021. La phénoménologie est-elle une théologie? Jan Patočka entre le tournant théologique et la tâche de penser. Paris: Institut Catholique de Paris, pp. 87-111.

Kohák, Erazim. 1989. Jan Patočka: Philosophy and Selected Writings. Chicago and London: The University of Chicago Press.

Masaryk, Tomáš Garrigue. 1938. Goethe’s Faust: Superman. In Modern Man and Religion. English Translation by Ann Bibza and Václav Beneš. London: George Allen, pp. 256-86. First published 1896.

Masaryk, Tomáš Garrigue. 1990. Masarykova Abeceda. Edited by Jaroslav Dresler. Prague: Melantrich. First published 1896.

Patočka, Jan. 1989. Titanism. In Jan Patočka: Philosophy and Selected Writings. Edited by Erazim Kohák. Chicago and London: The University of Chicago Press, pp. 139-44. First published 1936.

Patočka, Jan. 1996. Heretical Essays in the Philosophy of History. Translated by Erazim Kohák. Edited by James Dodd. Chicago and La Salle: Open Court. First published 1990.

Patočka, Jan. 2002. Duchovní člověk a intelektuál. In Péče o duši III. Sebrané spisy Jana Patočky. Edited by Ivan Chvatík and Pavel Kouba. Prague: Oikoymenh Filosofia, vol. 3, pp. 355-71. First published 1975.

Patočka, Jan. 2004a. Epičnost a dramatičnost, epos a drama. In Umění a čas I. Sebrané spisy Jana Patočky. Edited by Daniel Vojtěch and Ivan Chvatík. Prague: Oikoymenh Filosofia, vol. 4, pp. 348-58. First published 1966.

Patočka, Jan. 2004b. Vaculík a Kundera. In Uměni a čas II. Sebrané spisy Jana Patočky. Edited by Daniel Vojtěch and Ivan Chvatík. Prague: Oikoymenh Filosofia, vol. 5, pp. 211-13. First published 1968.

Patočka, Jan. 2004c. Pravda mýtu v Sofoklových dramatech o Labdakovcích. In Umění a čas I. Sebrané spisy Jana Patočky. Edited by Daniel Vojtěch and Ivan Chvatík. Prague: Oikoymenh Filosofia, vol. 4, pp. 461-67. First published 1971.

Patočka, Jan. 2004d. Německá duchovnost Beethovenovy doby. In Umění a čas I. Sebrané spisy Jana Patočky. Edited by Daniel Vojtěch and Ivan Chvatík. Prague: Oikoymenh Filosofia, vol. 4, pp. 468-88. First published 1971.

Patočka, Jan. 2004e. Faustovská legenda včera a dnes: Nad románem Thomase Manna Doktor Faustus. In Umění a čas II. Sebrané spisy Jana Patočky. Edited by Daniel Vojtěch and Ivan Chvatík. Prague: Oikoymenh Filosofia, vol. 5, pp. 105-19. First published 1972.

Patoč ka, Jan. 2004f. Smysl mýtu o paktu s d'áblem: Úvaha o variantách pověsti o Faustovi. In Umění a čas I. Sebrané spisy Jana Patočky. Edited by Daniel Vojtěch and Ivan Chvatík. Prague: Oikoymenh Filosofia, vol. 4, pp. 510-25. First published 1973.

Patočka, Jan. 2006a. Společenská funkce literatury. In Češi I. Sebrané spisy Jana Patočky. Edited by Karel Palek and Ivan Chvatík. Prague: Oikoymenh Filosofia, vol. 12, pp. 175-85. First published 1968.

Patočka, Jan. 2006b. Kolem Masarykovy filozofie náboženství. In Češi I. Sebrané spisy Jana Patočky. Edited by Karel Palek and Ivan Chvatík. Prague: Oikoymenh Filosofia, vol. 12, pp. 366-422. First published 1977.

Shelley, Percy Bysshe. 2006. Preface to Prometheus Unbound. In The English Anthology of English Literature, 8th ed. Edited by Stepehn Greenblatt. New York and London: W. W. Norton \& Company, vol. 2, pp. 775-78. First published 1820.

Svobodová, Zuzana. 2021. Jak dnes může promlouvat pověst o Faustovi? Studia Aloisiana 12: 23-39. 
Vanovič, Júlis. 1999. Osobnost' Václava Černého. Bratislava: Kalligram.

Veselý, Jindřich. 2013. Jan Patočka a křest'anství. Studia Philosophica 65: 63-84. Available online: https://digilib.phil.muni.cz/ bitstream/handle/11222.digilib/128396/1_StudiaPhilosophica_60-2013-2_5.pdf?sequence=1 (accessed on 2 July 2021).

Vojtěch, Daniel, and Ivan Chvatík. 2004. Ediční komentář. In Umění a čas II. Sebrané spisy Jana Patočky. Edited by Daniel Vojtěch and Ivan Chvatík. Prague: Oikoymenh-Filosofia, vol. 5, pp. 367-428. 